\title{
Rapidly Growing Acinar Cell Carcinoma of the Pancreatic Head: A Case Report and Literature Review
}

\author{
Eunhye Kang', Yoo-Shin Choi', Hyoung-Chul Oh², Jae Hyuk Do², Soon-Uk Hong ${ }^{3}$, Seung Eun Lee' \\ Departments of 'Surgery, ${ }^{2}$ Internal Medicine, and ${ }^{3}$ Pathology, Chung-Ang University College of Medicine, Seoul, Korea
}

Pancreatic acinar cell carcinoma (ACC) is a rare neoplasm accounting less than $1 \%$ of malignant pancreatic tumors. A 47-year-old male patient visited the emergency room with epigastric pain. Computed tomography or magnetic resonance imaging revealed a 4.7-cm heterogeneously enhanced solid and cystic mass with internal necrosis located in the head of the pancreas. Radiological diagnosis was borderline malignancy such as neuroendocrine tumor or solid pseudopapillary neoplasm. Two months later, the necrotic mass in the pancreas head had grown up to $11 \mathrm{~cm}$, compressing the duodenum, superior mesenteric vein, and proximal transverse colon. Pylorus preserving pancreatoduodenectomy with segmental resection of transverse colon was performed. Histopathological examination revealed that the tumor was pancreatic ACC. The patient recovered without any complication and was doing well without recurrence for 12 months after surgery.

Korean J Pancreas Biliary Tract 2022;27(1):54-59

\section{Keywords: Carcinoma; Acinar cell; Pancreas}

Received Aug. 26, 2021

Revised Nov. 25, 2021

Accepted Nov. 29, 2021

Corresponding author: Seung Eun Lee

Department of Surgery, Chung-Ang University Hospital, 102 Heukseok-ro, Dongjak-gu, Seoul 06973 , Korea

Tel. +82-2-6299-1545 Fax. +82-2-824-7869

E-mail; selee508@cau.ac.kr

ORCID: https://orcid.org/0000-0003-1830-9666

This is an Open Access article distributed under the terms of the Creative Commons Attribution Non-Commercial License (http:// creativecommons.org/licenses/by-nc/4.0/) which permits unrestricted non-commercial use, distribution, and reproduction in any medium, provided the original work is properly cited.

Copyright $\odot 2022$ by The Korean Journal of Pancreas and Biliary Tract

\section{INTRODUCTION}

Pancreatic acinar cell carcinoma (ACC) is a very rare malignant neoplasm accounting for less than $1 \%$ of primary pancreatic neoplasms. ${ }^{1}$ Because of the rarity of ACC, many issues such as diagnosis, surgical treatment, adjuvant therapy or therapeutic outcomes remain unclear. In general, although typical ductal adenocarcinoma is uncommonly confused for ACC, the preoperative diagnosis of ACC is difficult, imaging studies such as computed tomography (CT) or magnetic resonance imaging (MRI) only infrequently providing diagnostic clues and tissue diagnosis often requiring additional immunohistochemical assays. ${ }^{2,3} \mathrm{ACC}$ is often mistaken for pancreatic neuroendocrine tumor (PNET), solid pseudopapillary tumor (SPT) or pancreatoblastoma. ${ }^{2}$ For treatment strategy, curative-intent surgery should be proposed when the disease in localized, not differing from that of pancreatic ductal adenocarcinoma (PDAC). ${ }^{4}$ However, the role of adjuvant chemotherapy has not been proven and the prognostic factors are rarely investigated. Here, we report a case of rapidly growing pancreatic ACC and review the literature to better understand this rare form of pancreatic malignancy. 


\section{CASE}

A 47-year-old male visited Emergency Department of Chung-Ang University Hospital due to severe pain in the epigastric area lasting 1 week. On physical examination, there was mild tenderness in the right upper quadrant of the abdomen, but the examination results were otherwise negative. His past medical history was unremarkable. CT of the abdomen and pelvis revealed a $4.7 \mathrm{~cm}$ heterogeneously enhanced solid and cystic mass located in the head of the pancreas without obstruction of the biliary or pancreatic duct (Fig. 1A). MRI showed a well-defined hypo-enhancing mass with peripheral diffusion restriction, internal necrosis and peripancreatic infiltration with minimal fluid collection (Fig. 1B). The patient's serum lipase level was elevated at 2,138 IU/L (reference 67-21), while serum amylase level was 40 IU/L (reference 20-84) within normal range. All other laboratory parameters showed results within normal limits including carcinoembryonic antigen (CEA) and carbohydrate antigen 19-9 (CA19-9). CEA was $1.19 \mathrm{ng} / \mathrm{mL}$ (reference 0-3.8) and CA19-9 was 12.4 U/mL (reference 0-32). Owing to the patient's private business schedule, he refused to undergo operation at the initial visit and returned 2 months later. Over those 2 months, the necrotic mass in the pancreas head had grown up to $11 \mathrm{~cm}$, compressing the duodenum, superior mesenteric vein, and proximal transverse colon (Fig. 1C). However, because the tumor was thought to be resectable, without further work-up such as preoperative histologic diagnosis, surgery was performed. Exploration for the mass demonstrated involvement of the entire head of pancreas, transverse colon and its mesentery. Pylorus preserving pancreatoduodenectomy with segmental resection of transverse colon was performed (Fig. 2). Histopathological examination of the resected specimen revealed that the lesion consisted of highly cellular malignant epithelial tumor cells with scarce stroma and hemorrhage (Fig. 3A). Tumor cells were characterized by round nuclei with prominent nucleoli and acinar patterns (Fig. 3B). Immunohistochemistry demonstrated that the

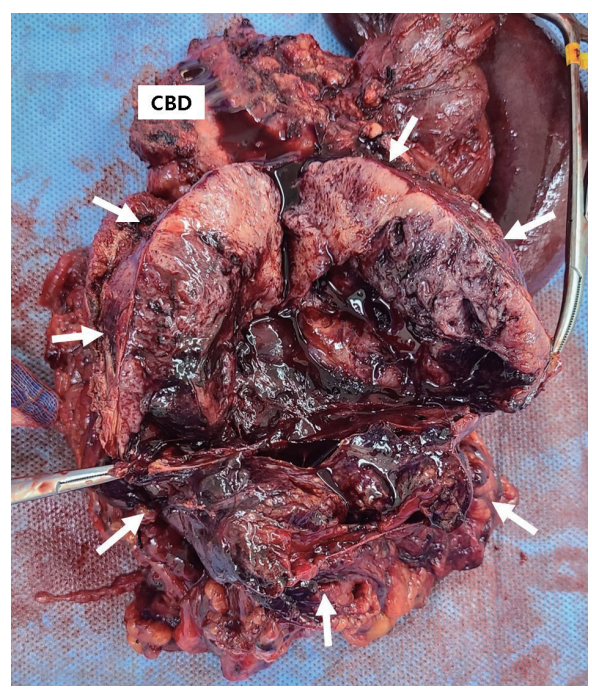

Fig. 2. Gross appearance of resected specimen. The bulky and lobulated solid tumor with central hemorrhage was located in the pancreas head. Arrows mark the boundaries of the tumor. CBD, common bile duct.
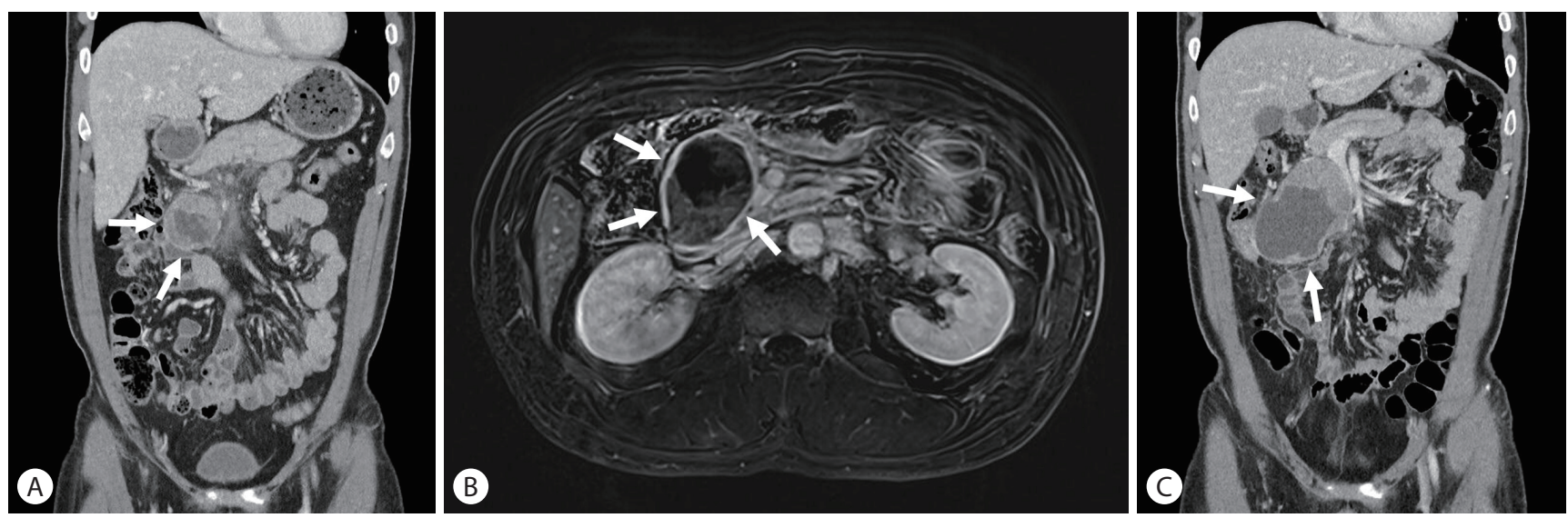

Fig. 1. (A) Abdominal computed tomography (CT) scan demonstrated 4.7-cm heterogeneously enhanced solid and cystic mass located in the head of the pancreas (arrows). (B) Magnetic resonance imaging showed a same sized well-defined hypo-enhancing mass with peripheral diffusion restriction, internal necrosis (arrows). (C) Two months later, abdominal CT scan demonstrated rapidly growing 11-cm sized necrotic mass (arrows). 
tumor cells were positive for trypsin (Fig. 3C), cytokeratin (CK), CK7, and E-cadherin. They were negative for CK19, chromogranin, synaptophysin and beta-catenin. These findings were consistent with those of pancreatic ACC. Tumor cells were observed to extend to the peripancreatic soft tissue without the presence of perineural invasion or regional lymph node metastasis. All surgical margins were tumor-free. The patient's postoperative course was uneventful. He rejected adjuvant chemotherapy and was doing well without recurrence for 12 months.

\section{DISCUSSION}

Pancreatic ACC is a rare neoplasm, although acinar cells are predominant in the normal pancreas. ${ }^{1}$ ACC have an expansile growth pattern with relatively good demarcation, so the invasion of the common bile duct is less than that of PDAC. ${ }^{2}$ Therefore, there are more cases of non-specific symptoms such as abdominal pain than jaundice. Pancreatic ACC is often misdiagnosed as PDAC, PNET, or SPT. Approximately $50 \%$ of patients experience hyperlipasemia, and 10-15\% of patients develop lipase hypersecretion syndrome, a type of paraneoplastic syndrome characterized by subcutaneous fat necrosis, polyarthralgia, and hypereosinophilia. ${ }^{3}$ Pancreatic ACC is usually an exophytic, well-marginated, and hypovascular mass on CT and MRI. And it may contain cystic areas due to necrosis in case of large size. ${ }^{4}$ Unlike ACC, PDAC is not well marginated and functioning PNET is more vascular. But, similar to ACC, non-functioning PNET may present as large well-marginated masses with internal hemorrhagic-cyst areas. ${ }^{4}$ And typical CT appearance of SPT is a large well-encapsulated mass with solid and cystic components caused by hemorrhagic degeneration. ${ }^{5}$ In terms of pathological diagnosis, ACC presents with different histological patterns, the
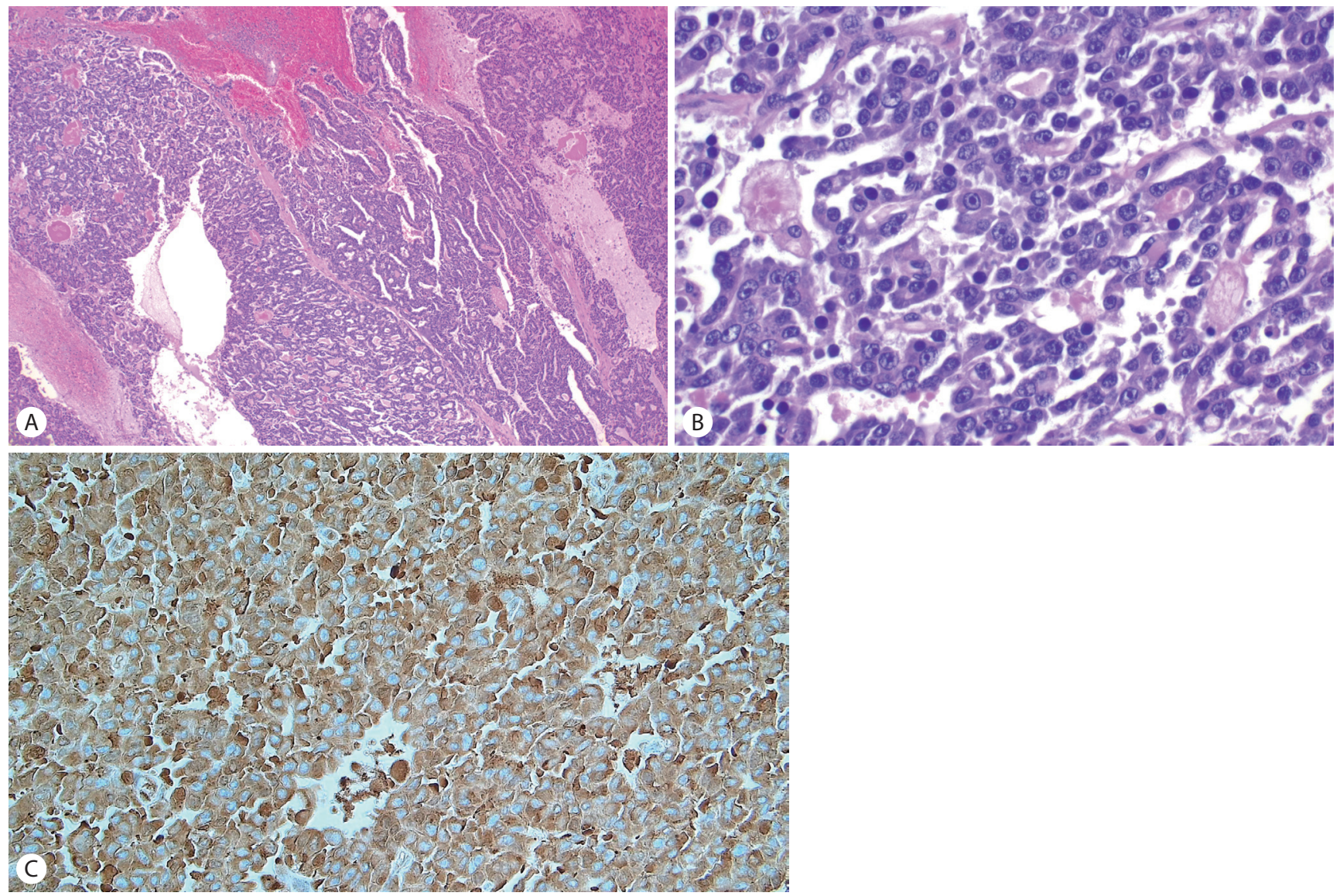

Fig. 3. Microscopic architectural pattern of acinar cell carcinoma. (A) Histological examination with hematoxylin and eosin staining (H\&E) ( $\times 100)$ revealed high cellular tumor with scarce stroma and hemorrhage and (B) tumor cells characterized by round nucleus with prominent nucleoli and acinar pattern $(H \& E, \times 400)$. (C) Tumor cells showed immunohistochemically positive for trypsin $(\times 400)$. 


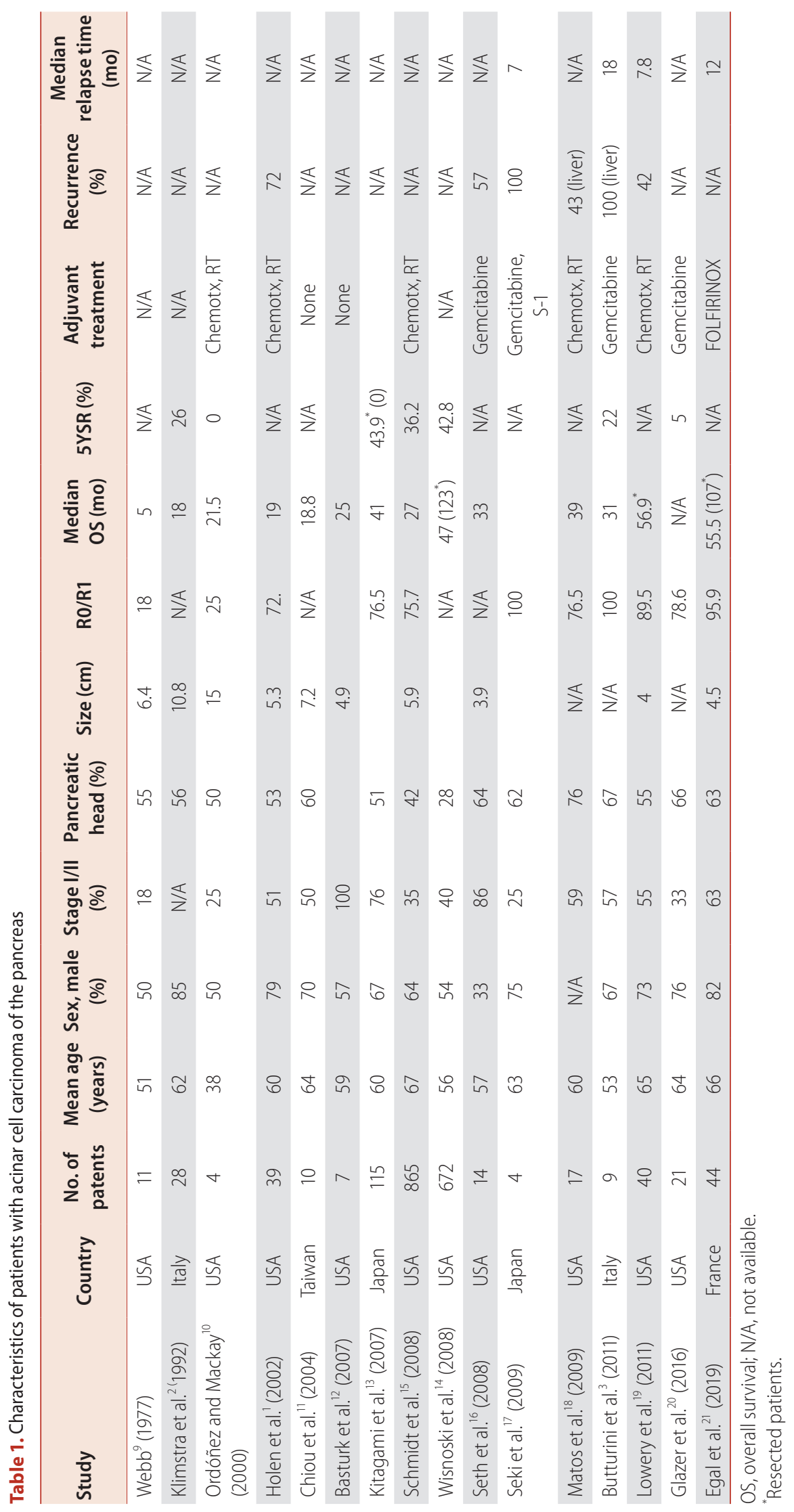


neoplastic cells are uniform and arranged in architectural patterns, most typically acinar or solid. ${ }^{2}$ The most common pancreatic neoplasm that are confused for ACC are PNET and SPT because of similar architectural pattern. Therefore, immunohistochemical staining for pancreatic enzymes including trypsin, chymotrypsin are used for diagnosis. ${ }^{3}$ Trypsin is found to be the most commonly expressed enzyme followed by lipase, chymotrypsin and amylase. Compared to other markers, synaptophysin, chromogranin A, E-cadherin were markers for PNET and vimentin, nuclear labeling of $\beta$-catenin were markers for SPT. ${ }^{6}$ Unlike that in PDAC, mutations of the K-ras oncogene, and the tumor suppressor gene p53 are not frequent in pancreatic ACC, however, chromosomal imbalances are common. ${ }^{7,8}$

We searched the medical literature for studies describing therapeutic management and clinical outcomes for ACC. Case series and case reports with more than four patients were included. Among a total 142 manuscripts, 16 studies were included and Table 1 shows the summary of the included studies. ${ }^{1-3,9-21}$ A total 1,901 patients were identified from the included studies had a mean age of 62 years, and $61 \%$ were men. In the present review, $40 \%$ of patients with ACC were located at pancreatic head and $41 \%$ of patients had resectable disease (stage I/II). There were three nation-wide study using national database, Japan pancreatic cancer registry, Surveillance, Epidemiology, and End Results (SEER) and National Cancer Database (NCDB). ${ }^{13-15}$ Among them, two studies from USA compared the clinical features and outcomes between ACC and PDAC. ${ }^{14,15}$ Patients with ACC were more likely to be male (63.5\% vs. $49.9 \%, 53.6 \%$ vs. $48.4 \%)$ and white ( $83.4 \%$ vs. $81.3 \%, 84.7 \%$ vs. $80.3 \%$ ). ACC was more frequently located in the body/tail of the pancreas compared to PDAC (27.4\% vs. $18.2 \%$, $32.8 \%$ vs. $16.4 \%$ ). More patients with ACC were presented with localized disease (34.6\% vs. $22.4 \%, 14.7 \%$ vs. $8.4 \%$ ) and curative resection rate was higher in the patients with ACC than in those with PDAC (64.35 vs. 55.9\%, 69.1\% vs. 27.3\%). Overall 5-year survival rate for patients with ACC was significantly better than that of patients with PDAC ( $42.8 \%$ vs. $3.8 \%) .{ }^{13}$ In all three national wide studies, surgical resection significantly improved overall 5 -year survival rate of the patients with ACC (43.9\% vs. 0.0\%, 72\% vs. $22 \%, 36.2 \%$ vs. $10.4 \%$ ). Surgery with any form of adjuvant therapy was associated with a better survival compared to patients who received surgery alone $(41.2 \%$ vs. $32.7 \%) .{ }^{15}$ Since no standard chemotherapeutic regimens have yet been established for ACC, similar chemotherapeutic regimens to those for PDAC have often been used. Recently, it has been reported that the administration of platinum- or irinotecan- containing chemotherapy regimens such as FOLFIRINOX, are effective for advanced ACC and further more prospective clinical trials are needed. ${ }^{22,23}$ Multivariate cox proportional hazard regression model suggested that survival of the patients with ACC was significantly better than that of the patients with PDAC (hazard ratio 0.24, 95\% confidence interval $0.22-0.27){ }^{14}$

Pancreatic ACC is a rare malignant disease that cannot be easily differentiated from other common pancreatic tumors preoperatively. However, compared with PDAC, ACC seems to have a better prognosis, especially after resection. Therefore, for the relatively younger male patients with large pancreatic tumor with cystic component like the present case, surgeons should keep ACC in mind and should perform resection and adjuvant chemotherapy actively.

\section{요 약}

췌장 선방세포암은 췌장암 중 $1 \%$ 미만을 차지하는 매우 드문 암으로, 수술 전 영상 검사상 췌장관세포암, 췌장 고형성가유두상 종양, 신경내분비 종양 등과 감별이 어려운 경우가 많다. 현재까지 명확하게 정립된 치료법은 없으며, 조기 진단 및 종양의 완전 절제만이 생존율 향상을 가져온다고 보고되고 있다. 그러나 췌장 관세포암에 비하여 종양 절제 후 비교적 좋은 예후를 보여준다. 본 증례와 같이 비교적 젊은 남자 환자가 낭성 부분을 포함한 크기가 큰 고형성 췌장 종양을 주소로 내원하였을 경우 췌장 선방세포암을 염두에 두고 적극적인 수술 치료를 고려해야할 것이다.

국문 색인: 암; 선방세포; 췌장

\section{Conflicts of Interest}

The authors have no conflicts to disclose. 


\section{ORCID}

$\begin{array}{ll}\text { Eunhye Kang } & \text { https://orcid.org/0000-0001-9955-8597 } \\ \text { Yoo-Shin Choi } & \text { https://orcid.org/0000-0003-3172-0329 } \\ \text { Hyoung-Chul Oh } & \text { https://orcid.org/0000-0003-0068-5030 } \\ \text { Jae Hyuk Do } & \text { https://orcid.org/0000-0002-2229-0024 } \\ \text { Soon-Uk Hong } & \text { https://orcid.org/0000-0002-7902-4608 } \\ \text { Seung Eun Lee } & \text { https://orcid.org/0000-0003-1830-9666 }\end{array}$

\section{REFERENCES}

1. Holen KD, Klimstra DS, Hummer A, et al. Clinical characteristics and outcomes from an institutional series of acinar cell carcinoma of the pancreas and related tumors. J Clin Oncol 2002;20:4673-4678.

2. Klimstra DS, Heffess CS, Oertel JE, Rosai J. Acinar cell carcinoma of the pancreas. A clinicopathologic study of 28 cases. Am J Surg Pathol 1992;16:815-837.

3. Butturini G, Pisano $M$, Scarpa A, D'Onofrio $M$, Auriemma A, Bassi C. Aggressive approach to acinar cell carcinoma of the pancreas: a single-institution experience and a literature review. Langenbecks Arch Surg 2011;396:363-369.

4. Tatli S, Mortele KJ, Levy AD, et al. CT and MRI features of pure acinar cell carcinoma of the pancreas in adults. AJR Am J Roentgenol 2005;184:511-519.

5. Choi JY, Kim MJ, Kim JH, et al. Solid pseudopapillary tumor of the pancreas: typical and atypical manifestations. AJR Am J Roentgenol 2006;187:W178-W186.

6. Ohara Y, Oda T, Hashimoto S, et al. Pancreatic neuroendocrine tumor and solid-pseudopapillary neoplasm: key immunohistochemical profiles for differential diagnosis. World J Gastroenterol 2016;22: 8596-8604.

7. Bergmann F, Aulmann S, Sipos B, et al. Acinar cell carcinomas of the pancreas: a molecular analysis in a series of 57 cases. Virchows Arch 2014;465:661-672.

8. Hoorens A, Lemoine NR, McLellan E, et al. Pancreatic acinar cell carcinoma. An analysis of cell lineage markers, p53 expression, and Ki-ras mutation. Am J Pathol 1993;143:685-698.

9. Webb JN. Acinar cell neoplasms of the exocrine pancreas. J Clin Pathol 1977;30:103-112.

10. Ordóñez NG, Mackay B. Acinar cell carcinoma of the pancreas. Ultrastruct Pathol 2000;24:227-241.
11. Chiou YY, Chiang JH, Hwang Jl, Yen CH, Tsay SH, Chang CY. Acinar cell carcinoma of the pancreas: clinical and computed tomography manifestations. J Comput Assist Tomogr 2004;28:180-186.

12. Basturk O, Zamboni G, Klimstra DS, et al. Intraductal and papillary variants of acinar cell carcinomas: a new addition to the challenging differential diagnosis of intraductal neoplasms. Am J Surg Pathol 2007;31:363-370.

13. Kitagami H, Kondo S, Hirano S, Kawakami H, Egawa S, Tanaka M. Acinar cell carcinoma of the pancreas: clinical analysis of 115 patients from Pancreatic Cancer Registry of Japan Pancreas Society. Pancreas 2007:35:42-46

14. Wisnoski NC, Townsend CM Jr, Nealon WH, Freeman JL, Riall TS. 672 patients with acinar cell carcinoma of the pancreas: a population-based comparison to pancreatic adenocarcinoma. Surgery 2008;144:141-148.

15. Schmidt CM, Matos JM, Bentrem DJ, Talamonti MS, Lillemoe KD, Bilimoria KY. Acinar cell carcinoma of the pancreas in the United States: prognostic factors and comparison to ductal adenocarcinoma. J Gastrointest Surg 2008;12:2078-2086.

16. Seth AK, Argani $P$, Campbell KA, et al. Acinar cell carcinoma of the pancreas: an institutional series of resected patients and review of the current literature. J Gastrointest Surg 2008;12:1061-1067.

17. Seki Y, Okusaka T, Ikeda M, Morizane C, Ueno H. Four cases of pancreatic acinar cell carcinoma treated with gemcitabine or S-1 as a single agent. Jpn J Clin Oncol 2009;39:751-755.

18. Matos JM, Schmidt CM, Turrini 0 , et al. Pancreatic acinar cell carcinoma: a multi-institutional study. J Gastrointest Surg 2009;13: 1495-1502.

19. Lowery MA, Klimstra DS, Shia J, et al. Acinar cell carcinoma of the pancreas: new genetic and treatment insights into a rare malignancy. Oncologist 2011;16:1714-1720.

20. Glazer ES, Neill KG, Frakes JM, et al. Systematic review and case series report of acinar cell carcinoma of the pancreas. Cancer Control 2016;23:446-454.

21. Egal A, Cros J, Surcek M, et al. Prognostic factors of acinar cell carcinomas: a study of 44 patients. Pancreas 2019;48:1393-1396.

22. Takahashi H, Ikeda M, Shiba S, et al. Multicenter retrospective analysis of chemotherapy for advanced pancreatic acinar cell carcinoma: potential efficacy of platinum- and irinotecan-containing regimens. Pancreas 2021;50:77-82.

23. Busch $E$, Werft W, Bougatf $N$, et al. Metastatic acinar cell carcinoma of the pancreas: a retrospective cohort study on systemic chemotherapy and review of the literature. Pancreas 2021;50:300-305. 